\title{
Production of isomaltulose obtained by Erwinia sp. cells submitted to different treatments and immobilized in calcium alginate
}

\author{
Produção de isomaltulose obtida por células de Erwinia sp. submetidas a \\ diferentes tratamentos e imobilizadas em alginato de cálcio
}

\author{
Haroldo Yukio KAWAGUTI ${ }^{1 *}$, Hélia Harumi SATO ${ }^{1}$
}

\begin{abstract}
In recent decades, there has been an increase in the studies of isomaltulose obtainment, due to its physicochemical properties and physiological health benefits. These properties, which include low cariogenicity, low glycemic index and greater stability, allow the use of this sweetener as a substitute for sucrose in foods; besides the fact that it can be converted to isomalt, a dietary non-cariogenic sugar alcohol used in pharmaceuticals as well as in the food industry. Isomaltulose (6-O- $\alpha$-D-glucopyronosyl-1-6-D-fructofuranose) is a disaccharide reducer obtained by the enzymatic conversion of sucrose - the $\alpha$-glucosyltransferase enzyme. Different treatments were performed for the preparation of whole cells; lysed cells; and crude enzyme extract of Erwinia sp. D12 strain immobilized in calcium alginate. The packed bed column of granules, containing Erwinia sp. cells sonicated and immobilized in calcium alginate (CSI), reached a maximum conversion of 53-59\% sucrose into isomaltulose and it presented activity for 480 hours. The converted syrup was purified and the isomaltulose crystallization was performed through the lowering of temperature. The isomaltulose crystals presented purity of $96.5 \%$.

Keywords: calcium alginate; immobilized cells; Erwinia sp.; isomaltulose.
\end{abstract}

\section{Resumo}

Nas últimas décadas, houve um incremento nos estudos da obtenção da isomaltulose, devido às suas propriedades físico-químicas e fisiológicas benéficas à saúde. Propriedades que incluem a baixa cariogenicidade, baixo índice glicêmico e maior estabilidade, propiciam o uso deste adoçante como substituinte da sacarose em alimentos, além de poder ser convertido para isomalte, um açúcar álcool dietético e não cariogênico aplicado na indústria de alimentos e farmacêutica. A isomaltulose (6-O- $\alpha$-D-glucopyronosyl-1-6-D-fructofuranose) é um dissacarídeo redutor obtido através da conversão enzimática da sacarose, pela enzima $\alpha$-glicosiltransferase. Foram realizados diferentes tratamentos para a preparação de células íntegras, células lisadas e extrato enzimático bruto da linhagem Erwinia sp. D12 imobilizados em alginato de cálcio. A coluna de leito empacotado de grânulos contendo células de Erwinia sp. sonicadas e imobilizadas em alginato de cálcio (CSI) atingiu máxima conversão de 53-59\% de sacarose em isomaltulose e apresentou atividade por 480 horas. O xarope convertido foi purificado e a cristalização da isomaltulose foi realizada por abaixamento de temperatura. Os cristais de isomaltulose apresentaram pureza de 96,5\%.

Palavras-chave: alginato de cálcio; células imobilizadas; Erwinia sp.; isomaltulose.

\section{Introduction}

Sucrose is the most widely used sweetener in food production due to its physicochemical and sensorial characteristics. However, because of its high calorific value and cariogenic properties, alternative sweeteners are being studied. Foods that promote a state of well being associated with health improvement and low risks of disease have become popular, as consumers are becoming more aware and well informed. For this reason, substitutes of sucrose in are being researched.

In the past two decades, there has been an increasing interest in the production of isomaltulose, also known as Palatinose (BUCHHOLZ; SEIBEL, 2008). Isomaltulose has a mild sweet taste, about $50 \%$ of the sweetness of sucrose (SHIMIZU; SUZUKI; NAKAJIMA, 1982; HASHIMOTO; YAMADA; OSHIMURA, 1987; HUANG; HSU; SU, 1998) and it has very similar physicochemical and sensorial properties when used in food, and when used as a substitute for sucrose, no difference in sweetness was noticed (HUANG; HSU; SU, 1998; CHEETHAM; IMBER; ISHERWOOD, 1982; TAKAZOE, 1989).

Isomaltulose contains lower cariogenic potential and it has been used commercially in Japan as an ingredient and substitute for sucrose in the production of chewing gum, yogurt, sweets and beverages (HUANG; HSU; SU, 1998). It also offers a low rate of hydrolysis and formation of monosaccharides in the body and it is recommended as an ingredient in food and beverages for diabetic persons and athletes (KRASTANOV; YOSHIDA, 2003; KASHIMURA; NAGAI; GODA, 2008; HÄBERER et al., 2009).

Recebido para publicação em 31/7/2009

Aceito para publicação em 1/11/2009 (004321)

${ }^{1}$ Laboratório de Bioquímica de Alimentos, Departamento de Ciência de Alimentos, Faculdade de Engenharia de Alimentos, Universidade Estadual de Campinas - UNICAMP, CP 6121, CEP 13083-862, Campinas - SP, Brasil, E-mail: kawaguti@fea.unicamp.br

${ }^{*}$ A quem a correspondência deve ser enviada 
Many isomaltulose-derived products have potential industrial applications. Items such as intermediate disaccharides, polymers such as biodegradable detergents, and surfactants for industrial use, may be obtained from isomaltulose (LICHTENTHALER; PETERS, 2004). Isomaltulose can also be applied to produce isomaltulose oligomers, which act as prebiotics, stimulating proliferation of intestinal microbiota bifidobacteria (KASHIMURA; KIMURA; ITOKAWA, 1996). The main isomaltulose derivative is isomalt, a sugar-alcohol obtained through hydrogenation, resulting an equimolar mixture of [6-O-( $\alpha$-D-glucopyranosyl)-D-sorbitol] and [1-O-( $\alpha$-D-glucopyranosyl)-D-mannitol], a non-cariogenic compound with low caloric value.

Microbial conversion of sucrose into isomaltulose has attracted great commercial interest due to its complexity of chemical synthesis. Isomaltulose is currently produced in large scale through the use of stable continuous columns of immobilized cells (WU; BIRCH, 2005). Alginate is one of the most commonly used supports for immobilizing whole microbial cells (VORLOP; KLEIN, 1983), because its use is simple and cheap; it is also a reproducible technique and moderate during the immobilization process (HULST; TRAMPER, 1989). The present paper depicts the conversion of sucrose into isomaltulose by immobilized Erwinia sp. D12 cells with calcium alginate. The cells were submitted to different treatments during and after immobilization with alginate support.

\section{Materials and methods}

\subsection{Microorganism and culture maintenance}

The Erwinia sp. D12 strain is a producer of the intracellular glucosyltransferase enzyme, which is capable of converting sucrose into isomaltulose, which was used in this study. The organism was grown in slants with medium composed of $6.0 \%$ sucrose (w/v), $4.0 \%$ peptone (w/v), $0.4 \%$ meat extract (w/v) and $2.0 \% \operatorname{agar}(\mathrm{w} / \mathrm{v})$ for 15 hours at $30^{\circ} \mathrm{C}$.

\subsection{Production of glucosyltransferase from Erwinia sp. D12 in $6.6 \mathrm{~L}$ of fermentor}

The wet cell mass of the Erwinia sp. D12 strain was obtained by the fermentation of the microorganism in culture medium composed of 160 g.L. $\mathrm{L}^{-1}$ of sugarcane molasses, 20 g.L $\mathrm{L}^{-1}$ of bacteriological peptone and 15 g. $\mathrm{L}^{-1}$ yeast extract Prodex Lac SD ${ }^{\otimes}$ (KAWAGUTI; MANRICH; SATO, 2006) in $6.6 \mathrm{~L}$ of New Brunswick Bioflo IIc fermentor (New Brunswick Scientific, Edison, NJ, USA) (KAWAGUTI; MANRICH; SATO, 2006). After fermentation, the cell mass was recovered by centrifugation at $9,600 \times \mathrm{g}$ for 15 minutes at $5^{\circ} \mathrm{C}$ and then washed twice in aseptic conditions, with previously sterile distilled water.

\subsection{Study of the conversion of sucrose into isomaltulose in a batch process}

Different methods of immobilization using calcium alginate were investigated, as well as the influence of the conversion of sucrose into isomaltulose. The tests were initially performed in batches by using Erlenmeyer flasks under agitation and, subsequently, columned in a packed bed. The cell mass of Erwinia sp. D12 was obtained from the fermentation in the optimized culture medium as described in item 2.2.

For the immobilization, from cell suspension containing $40 \%$ (w/v) wet cells of Erwinia sp. D12, in sterile distilled water, the cells were mixed with a $2 \%$ sterile solution $(\mathrm{w} / \mathrm{v})$ of sodium alginate Synth $\mathrm{PA}^{\star}$ (Labsynth products for laboratory Ltda. Diadema, SP, Brazil) containing 0.1\% (w/v ) Tween ${ }^{\circledast} 80$ (Riedel-deHaën, Seelze, Germany) in the proportion of 1:2 (v:v). Then, the suspension was dripped with the aid of a peristaltic pump MasterFlex ${ }^{\circledast} \mathrm{L} / \mathrm{S}$ (Cole-Parmar Instruments Co., Vernon Hills, IL, USA) in $2 \%$ (w/v) solution of $\mathrm{CaCl}_{2}$, previously sterile, to form small granules, which were kept immersed in the solution at $5^{\circ} \mathrm{C}$ for 12 hours. Subsequently, the granules were washed with distilled water to remove any $\mathrm{CaCl}_{2}$ excess. All steps were performed under aseptic conditions. For immobilization, samples of $25 \mathrm{~mL}$ of $40 \%$ (w/v) cell mass suspension were subjected to different treatments as described below:

- Immobilized Whole Cells (CII): The suspension of the cell mass was immobilized as described above; the granules were treated with a $0.06 \%(\mathrm{v} / \mathrm{v})$ glutaraldehyde solution for 20 minutes, under agitation, and then washed with sterile distilled water;

- Dried Immobilized Whole Cells (CIIS): The suspension of cell mass was immobilized as described for CII. After that, the granules containing immobilized cells were transferred to Petri dishes covered with a paper towel and kept for 24 hours refrigerated at $5{ }^{\circ} \mathrm{C}, 8$ hours in a laminar flow, then at room temperature for a further 16 hours, and then back to $5^{\circ} \mathrm{C}$ refrigeration for drying;

- Immobilized Sonicated Cells (CSI): The suspension of the cell mass was cooled to $5{ }^{\circ} \mathrm{C}$ and subjected to treatment in a Labline Ultra-Tip sonicator for 40 seconds, with 180-200 W. After the lysis of the cell wall, the cells and the extract containing glucosyltransferase were immobilized as described above, and the granules were treated with a glutaraldehyde solution as described for CII;

- Dried Immobilized Sonicated Cells (CSIS): The suspension of cell mass was treated and immobilized as described for CSI, and the granules were dried as described in CIIS;

- Immobilized Sonicated Cells Treated with Glutaraldehyde (CSGI): The mass of the cell suspension was sonicated as described for CSI. Then, $0.06 \%$ (v/v) of glutaraldehyde was added and the suspension was agitated for 20 minutes. The suspension containing lysed cells, glucosyltransferase and glutaraldehyde was immobilized as described above;

- Dried Immobilized Sonicated Cells Treated with Glutaraldehyde, (CSGIS): The wet cell mass was treated and immobilized as described for CSGI, and the granules were dried as described in CIIS;

- Crudely Immobilized Enzyme Extract (EEI): The suspension of cell mass was cooled to $5^{\circ} \mathrm{C}$ and subjected to treatment in a sonicator for 40 seconds, with 
180-200 W. After the lysis of the cell wall, the suspension was centrifuged at $7,800 \times \mathrm{g}$ at $5{ }^{\circ} \mathrm{C}$ for 15 minutes. Subsequently, the crude enzyme extract was stopped and the granules were treated with a $0.06 \%$ glutaraldehyde solution (v/v), and then washed as described above;

- Dried Immobilized Crude Enzyme Extract (EEIS): The suspension of cell mass was treated and the crude enzyme extract was immobilized as described for EEI, and the granules were dried as described in CIIS;

- Immobilized Crude Enzyme Extract Treated with Glutaraldehyde (EEGI): The suspension of cell mass was treated as described for EEI. Then $0.06 \%(\mathrm{v} / \mathrm{v})$ glutaraldehyde was added to the crude enzyme extract and the solution was agitated for 20 minutes. The crude enzyme extract containing glutaraldehyde was then immobilized as previously described; and

- Dried Immobilized Crude Enzyme Extract Treated with Glutaraldehyde (EEGIS): The crude enzyme extract was obtained, treated with glutaraldehyde, immobilized as described for EEGI, and dried as described in CIIS.

Samples of $12.5 \mathrm{~g}$ of dry or moist granules obtained from $12.5 \mathrm{~g}$ of wet granules were transferred to $250 \mathrm{~mL}$ Erlenmeyer flasks containing a solution of $100 \mathrm{~mL}$ with $35 \%$ (w/v) sucrose and then incubated on a rotary shaker at $150 \mathrm{rpm}$ at $30^{\circ} \mathrm{C}$. Samples of $100 \mathrm{~mL}$ of sugar solution were removed five times after 24 hours and they were replaced by new samples of sucrose solution $35 \%$ to complete 120 hours of granule use. The conversion of sucrose into isomaltulose was analyzed as described below:

- Carbohydrate Analysis by Anion-Exchange Liquid Chromatography with a High-Efficiency for Pulse Amperometric Detection (HPAEC-PAD): The carbohydrate analysis was performed in a Dionex DX-600 (Dionex Corporation, 1228 Titan Way Sunnyvale, CA, USA) chromatograph equipped with IP25 isocratic pump and gold electrochemical detector ED50. The separation of sugars was performed using a column CarboPacTM PA $1(4 \times 250 \mathrm{~mm})$, a guard column of CarboPacTM PA 1 $(4 \times 50 \mathrm{~mm})$ and sodium hydroxide solution $250 \mathrm{mM}$ as a mobile phase with a flow of $1 \mathrm{~mL} /$ minute at $20^{\circ} \mathrm{C}$. The carbohydrates were analyzed by retention time compared to standards of fructose, glucose, sucrose and isomaltulose (Sigma Ultra ${ }^{\circledast}$, Sigma Chemical Co., St. Louis, MO, USA).

\subsection{Production of isomaltulose using granules containing crude enzyme extract (EEI) and sonicated cells (CSI) from Erwinia sp. D12, immobilized in calcium alginate in packed bed columns}

The continuous conversion of sucrose into isomaltulose using crude enzyme extract containing granules (EEI) and sonicated cells (CSI) from Erwinia sp. immobilized in calcium alginate in packed bed columns was tested.

The granules were prepared as described in Section 2.3, washed with sterile distilled water and packed into heat proof columns. A 35\% (w/v) sucrose solution of P.A. Synth ${ }^{\circledast}$ (Labsynth
Laboratory Products Ltda. Diadema, Brazil) was circulated upwards continuously, with flow of $0.56 \mathrm{~mL} / \mathrm{minute}$. The column temperature was maintained at $30{ }^{\circ} \mathrm{C}$ and the conversion of sucrose into isomaltulose was analyzed, as described above, to determine the lifetime and stability of the column.

\subsection{Isomaltulose obtainment by crystallization}

The steps of clarification, purification and crystallization of isomaltulose were performed according to Moraes et al. (2005), with modifications.

- Syrup Clarification: the syrup containing high levels of isomaltulose was clarified with the aid of Romicon Ultrafiltration System ${ }^{\circledast}$ comprising a centrifugal pump of $20 \mathrm{gpm}$ (76 L/minute) and an ultrafiltration column containing PM 50 (50,000 Da) membrane;

- Syrup Purification: the syrup clarified by ultrafiltration was purified through chromatography cation exchange, on Dowex 88 column $(4 \times 30 \mathrm{~cm})$; and anionic exchange, on Dowex MSA1 column $(4 \times 30 \mathrm{~cm})$, at room temperature. Subsequently, the deionized syrup was treated with activated charcoal (LF310) at a concentration of $0.1 \%$ $(\mathrm{w} / \mathrm{v})$. The syrup was in contact with coal for 30 minutes at $45-50{ }^{\circ} \mathrm{C}$. Then, the syrup was vacuum pre-filtered using a Celite 508; finally, the resulting product was filtered in a $0.45 \mu \mathrm{m}$ membrane; and

- Crystallization: The purified syrup was concentrated to about $69 \%(\mathrm{w} / \mathrm{v})$ in a rotary evaporator (Rotavapor RE 120) and the crystallization was performed by slowly lowering the temperature. The syrup was incubated in a water bath, initially at $50{ }^{\circ} \mathrm{C}$, and subjected to continuous agitation. The water bath was programmed to lower $5{ }^{\circ} \mathrm{C}$ /hour between $50{ }^{\circ} \mathrm{C}$ and $35^{\circ} \mathrm{C}$. The syrup was seeded with isomaltulose crystals to aid crystallization. The crystals formed were collected by continuous centrifugation in a bench centrifuge, equipped with a nylon basket. The drying of the isomaltulose crystals was performed in a vacuum oven.

\section{Results and discussion}

\subsection{Study of the conversion of sucrose into isomaltulose in a batch process}

The study of the conversion of sucrose into isomaltulose using the granules containing whole cells, lysed cells and crude enzyme extract of glucosyltransferase from Erwinia sp. D12 immobilized in calcium alginate, submitted to different treatments in the batch process, was conducted in accordance with item 2.3. Figure 1 shows the wet and dry cells granules and crude extract of glucosyltransferase from Erwinia sp. D12 immobilized in calcium alginate, which were tested for the conversion of sucrose into isomaltulose.

Figure 2 shows the conversion of sucrose into isomaltulose using wet or dry granules containing whole cells, and crude extracted sonicated cells of glucosyltransferase, immobilized in calcium alginate, with and without glutaraldehyde treatment, in 

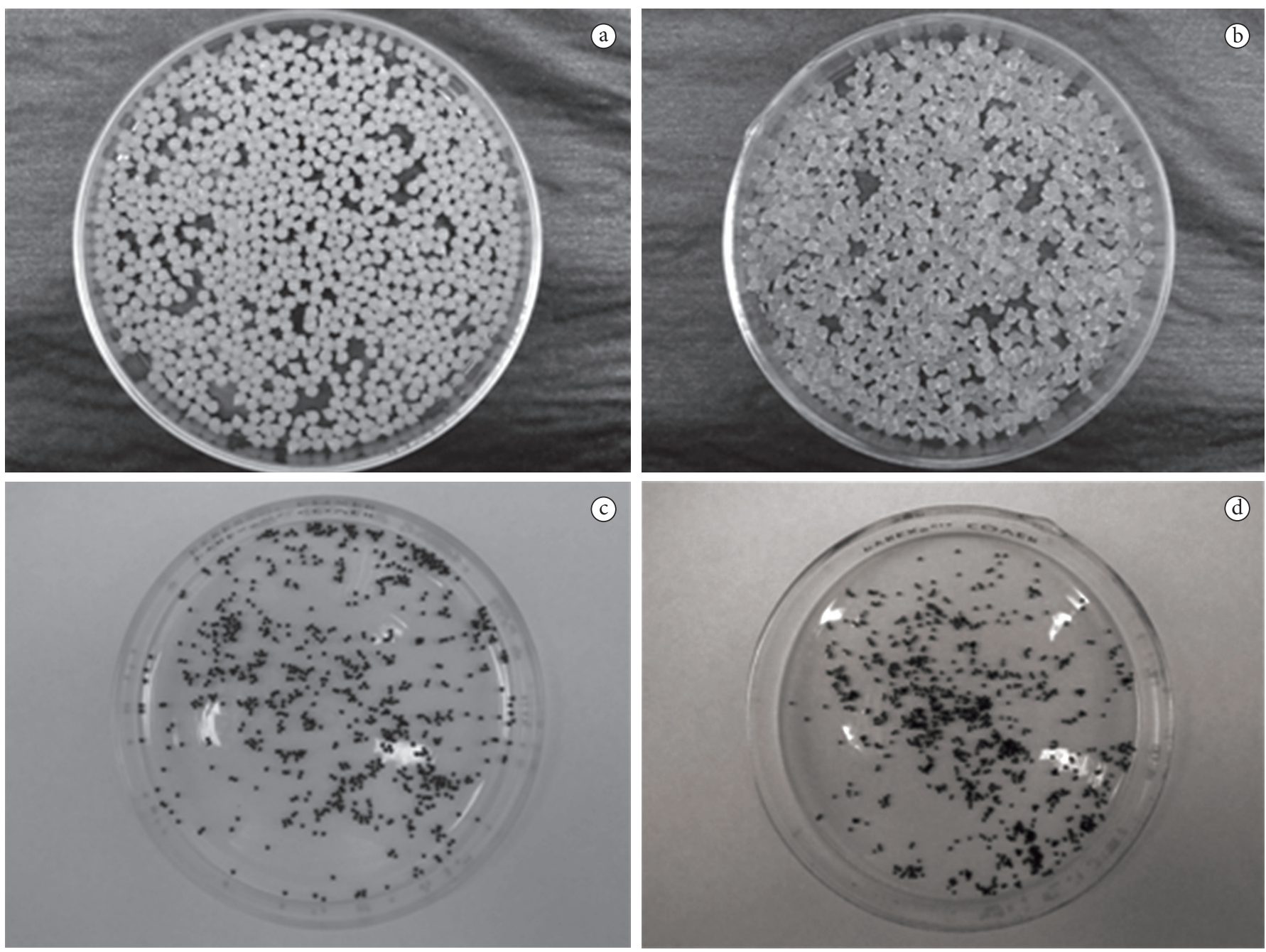

Figure 1. Granules containing cells or crude enzyme extract of glucosyltransferase from Erwinia sp. D12 immobilized in calcium alginate: a) Wet granules of whole immobilized cells (CII); b) Crude enzyme extract and immobilized wet granules (EI); c) Dried immobilized granules of whole cells (CIIS); and d) Immobilized and dry crude enzyme extract granules (EEIS).

the batch process. The samples that were more efficient - both in relation to the profit in isomaltulose as well as in the stability of the conversion - were the granules containing crude enzyme extract immobilized in calcium alginate (EEI), which showed stability over five batches obtained in conversion rates between 59.7-63.7\%; and the granules of sonicated cells immobilized in calcium alginate (CSI) showed a conversion rate between $47.6-62.6 \%$.

The granules of the enzyme extract treated with glutaraldehyde and immobilized in calcium alginate (EEGI) showed a high conversion rate in the first two batches, which were obtained in 63.3 and $64.3 \%$ of isomaltulose, however, there was a decrease in the conversion and $40.7 \%$ of isomaltulose was obtained in the fifth batch. The dried granules of whole immobilized cells (CIIS) and sonicated immobilized cells (CSIS) that showed the range of conversion $49.3-57.2 \%$ and 40.3-58.0\%, respectively, also showed good stability. The wet granules of crude enzyme extract (EEI) and sonicated cells (CSI), immobilized in calcium alginate, which showed higher conversion of sucrose into isomaltulose, were tested and then put in packed bed columns.

\subsection{Production of isomaltulose using granules containing crude enzyme extract (EEI) and sonicated cells (CSI) from Erwinia sp. D12, immobilized in calcium alginate, in packed bed columns}

Figure 3 shows that, in the first three days, there was a higher conversion using EEI, which was obtained at 59.6, 62.9 and $62.1 \%$ of isomaltulose. However, after the third day, there was a gradual decrease of the sucrose conversion into isomaltulose. Moreover, after nineteen days of continuous use, the granules of immobilized crude enzyme extract (EEI) showed no further activity.

In the first three days the CSI column showed a conversion of $58.4,57.8$ and $56.9 \%$ of sucrose into isomaltulose. It was observed that the CSI column showed superior stability on the EEI, but the conversion drop started as from the ninth day and 


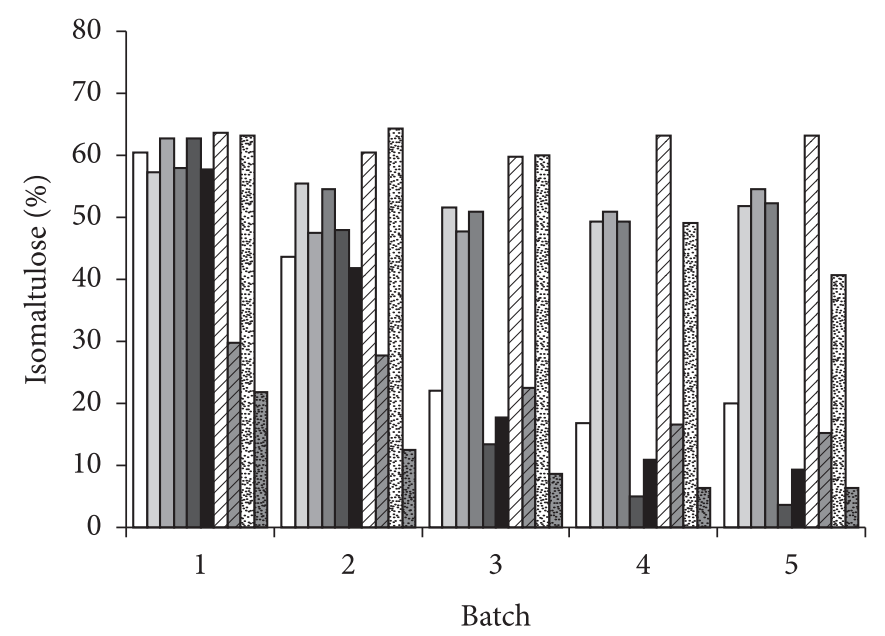

Figure 2. Conversion of sucrose into isomaltulose using wet or dry granules, containing whole cells, and cells treated with glucosyltransferase crude extract, immobilized in calcium alginate, with and without treatment with glutaraldehyde, in the batch process. [() Isomaltulose-CII:\% of Isomaltulose obtained from immobilized whole cells; (ם) Isomaltulose-CIIS:\% of Isomaltulose obtained from the Immobilized and Dry Cells; ( $\square$ )Isomaltulose-CSI:\% of Isomaltulose obtained from Sonicated Immobilized Cells; ( ) Isomaltulose-CSIS:\% of Isomaltulose obtained from Sonicated, Immobilized and Dry Cells; (匹) Isomaltulose-CSGI:\% of Isomaltulose obtained from Sonicated Cells treated with Glutaraldehyde and Immobilized; ( $\square$ ) IsomaltuloseCSGIS:\% of Isomaltulose obtained from Sonicated Cells treated with Glutaraldehyde, Immobilized and Dried; ( $\square$ ) Isomaltulose-EEI:\% of Isomaltulose obtained from Immobilized Crude Enzyme Extract; (घ) Isomaltulose-EEIS:\% of Isomaltulose obtained from Immobilized Dry Crude Enzyme Extract; (圈) Isomaltulose-EEGI:\% of Isomaltulose obtained from Crude Enzyme Extract treated with Glutaraldehyde and Immoblized; (⿴囗口) Isomaltulose-EEGIS:\% of Isomaltulose obtained from Crude Enzyme Extract treated with Glutaraldehyde, Immobilized and Dry].

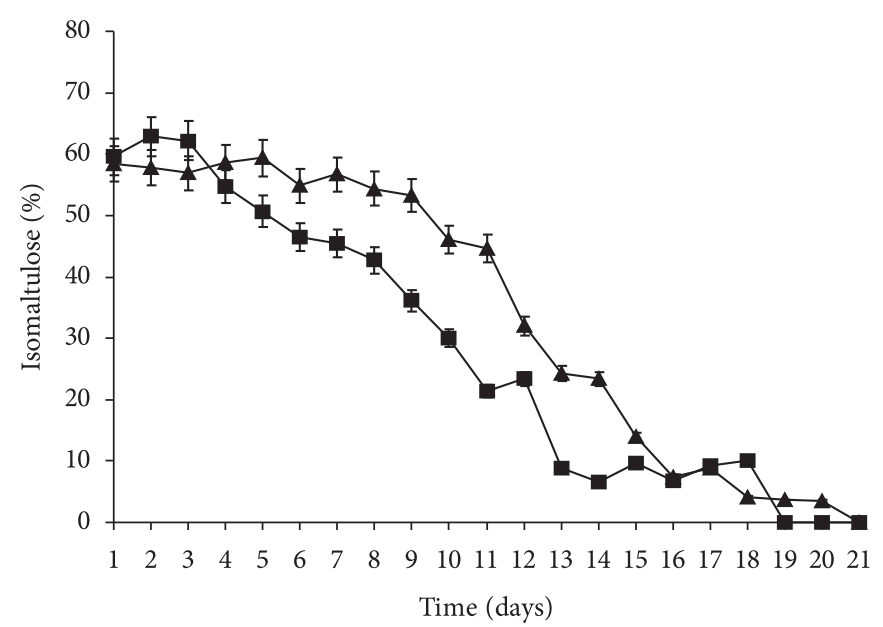

Figure 3. Conversion of sucrose into isomaltulose using granules from crude enzyme extract (EEI) sonicated cells (CSI) from Erwinia sp. D12, immobilized in calcium alginate in packed bed columns ( $\boldsymbol{\Delta}$ isomaltulose-CSI:\% of isomaltulose obtained from the sonicated immobilized cells in calcium alginate; $\boldsymbol{\square}$ isomaltulose-EEI:\% of isomaltulose obtained from the Immobilized Crude Enzyme Extract in calcium alginate). it obtained a profile of the drop in the conversion of sucrose into isomaltulose column similar to the EEI and, after twenty one days of continuous use, the granules of immobilized sonicated cells showed no activity of glucosyltransferase.

Other studies also reported the conversion of sucrose into isomaltulose in continuous process, using microbial cells immobilized in calcium alginate, such as cells of Erwinia rhapontici (CHEETHAM; GARRETT; CLARK, 1985) and Erwinia rhapontici BN68689 (AHN et al., 2003). However, to compare the results with reported literary data, the methodology for analysis of carbohydrates and the conditions for conversion of sucrose into isomaltulose should be considered.

Cheetham, Garret and Clark (1985) reported that cells of Erwinia rhapontici NC PPB 1578, immobilized in calcium alginate granules, showed conversion of approximately $90 \%$ of sucrose into isomaltulose. The carbohydrates were analyzed by the liquid chromatograph Waters Prep LC/system 500A with a refractive index detector and a column PrepPak $500 / C 18$. The high amount of isomaltulose could be due not to the chromatographic separation of isomer isomaltulose and trealulose, because the old equipment did not have the ability to separate as the new ion exchange liquid chromatography does. In this case, the two isomers may have been regarded as isomaltulose. In this study, the detention cell was made up by mixing the cell suspension to a $20 \%$ solution of $5 \%$ sodium alginate. The half-life of immobilized cells in the $200 \times 15 \mathrm{~cm}$ column was approximately 8,600 hours in continuous process at $30{ }^{\circ} \mathrm{C}$, using $1.6 \mathrm{M}$ sucrose solution adjusted to a $\mathrm{pH}$ of 7.0.

Tsuyuki et al. (1992) reported the detention of a suspension of $40 \%$ of plant cells of Klebsiella 10 MX 5\% solution of alginate to convert sucrose into isomaltulose. The granules were treated with $2 \%$ solution of polyethyleneimine for 5 minutes and, later, with $0.5 \%$ glutaraldehyde solution for 20 minutes. The immobilized cells, packed into columns $(50 \times 180 \mathrm{~mm})$, fully converted the $25 \%$ sucrose solution and obtained $65.4 \%$ of isomaltulose and $29.7 \%$ of trehalulose. Ahn et al. (2003) used the strain Erwinia rhapontici BN68689 to convert sucrose into isomaltulose. The detention was made from $40 \%$ cell suspension $(\mathrm{w} / \mathrm{v})$, mixed with equal volume of $5 \%$ sodium alginate solution. The granules were packed into columns $(180 \times 50 \mathrm{~mm}$ and capacity of $300 \mathrm{~mL}$ ) at $30{ }^{\circ} \mathrm{C}$ and fed with sucrose solution of $55 \%(\mathrm{w} / \mathrm{v}) \mathrm{pH} 7.0$. Temperatures were tested at $27^{\circ} \mathrm{C}, 30^{\circ} \mathrm{C}$ and $33^{\circ} \mathrm{C}$, and the initial profits of isomaltulose were respectively 79 , 89 and $85 \%$, and then decreased to 67,79 and $57 \%$ after 60 days, respectively. The carbohydrates were analyzed by a Waters 410 liquid chromatograph with a detection refractive index.

Protaminobacter rubrum cells immobilized in calcium alginate have been used to obtain isomaltulose (HASHIMOTO; YAMADA; OSHIMURA, 1987). The maximum immobilized cell activity, at a $\mathrm{pH}$ of 5.5, was observed after 3 hours and it was proportional to the amount of cells, yielding conversions of 18,30 and $44 \%$ for 10,20 and $40 \mathrm{mg}$ of cells. $\mathrm{mL}^{-1}$ of solution, respectively.

Moraes et al. (2005) obtained the maximum conversion of sucrose into $56.4 \%$ isomaltulose when a $19.4 \%$ sucrose solution was circulated through packed bed columns $(25 \times 200 \mathrm{~mm})$ 
containing immobilized cells of Erwinia sp. D12 (20\% cell suspension in alginate solution of $1 \%$ ) at a substrate flow of $21.88 \mathrm{~mL} /$ hour and temperature of $35{ }^{\circ} \mathrm{C}$. Mundra, Desai and Lele (2007) studied the effect of various immobilization parameters on converting sucrose into isomaltulose by immobilized cells of Erwinia rhapontici NCPPB 1578. Using a $30 \%$ sucrose solution, the maximum production of $140 \mathrm{mg} \cdot \mathrm{mL}^{-1}$ was obtained in a batch process when cells were suspended at 5 g.L. $\mathrm{L}^{-1}$ and immobilized in $5 \%$ sodium alginate.

News matrix and others methodologies of immobilization have been used to convert sucrose into isomaltulose in continuous process. Serratia plymuthica cells were immobilized in chitosan (KRASTANOV et al., 2006). The effect of the substrate sucrose concentration, the temperature and the residence time of the substrate solution on the specific volumetric productivity of the biocatalyst in a tubular fixed bed reactor was studied. A residence time of 1.7-3.0 hours was necessary for the achievement of $98-100 \%$ conversion of sucrose at substrate concentration of $30-50 \%$. A longer residence time (4-5 hours) was needed for reaching the same conversion rate of concentrated sucrose solutions (60-70\%). Krastanov, Blazheva and Stanche (2007) used immobilized cells of Serratia plymuthica in hollow fiber bioreactor to produce isomaltulose from sucrose solution. The specific productivity of the membrane reactor was $16.8 \mathrm{~g} \mathrm{~m}$-2/hours using a flow rate of $1.3 \mathrm{~cm}^{3} /$ minutes and $40 \%$ substrate concentration in continuous mode of action. The activity of the biocatalyst decreased with the increase of the operation time.

In this study, the continuous conversion of $35 \%$ solution of sucrose into isomaltulose in a packed bed column, using cells of Erwinia sp. lysed by ultrasonication and immobilized in calcium alginate (CSI), obtained 50-60\% of isomaltulose for nine days.

\subsection{Syrup crystallization}

The steps of clarification, purification and crystallization of the isomaltulose syrup were performed as described in item 2.5. The sugar crystals were analyzed and showed 96.5\% of isomaltulose. The yield of isomaltulose was obtained only through a process of crystallization and it can be obtained from a pure product if recrystallized. Cheetham (1987) obtained crystals containing $99 \%$ of isomaltulose after two crystallization processes.

\section{Conclusions}

The conversion of sucrose into isomaltulose was performed in a batch process using granules containing immobilized crude enzyme extract (EEI), which presented a conversion rate between 59.7-63.3\%; and granules containing immobilized cells lysed by ultrasonication (CSI), which showed a conversion rate between 47.6-62.6\%. The packed bed column containing pellets of cells of Erwinia sp. sonicated and immobilized in calcium alginate (CSI), showed higher stability obtained of 53-59\% isomaltulose after seven days. More studies should be performed to obtain greater stability of the immobilized glucosyltransferase in the form of whole cells, lysed cells or enzyme extract. The crystals of isomaltulose after syrup clarification and purification converted to $96.5 \%$ purity.

\section{Acknowledgements}

The authors would like to thank 'CAPES' and 'CNPq' for the granting of financial support.

\section{References}

AHN, S. J. et al. Enhanced conversion of sucrose to isomaltulose by a mutant of Erwinia rhapontici. Biotechnology Letters, v. 25, p. 1179-1183, 2003.

BUCHHOLZ, K.; SEIBEL, J. Industrial carbohydrate biotransformations. Carbohydrate Research, v. 343, p. 1966-1979, 2008.

CHEETHAM, P. S. J. Production of isomaltulose using immobilized microbial cells. Methods in Enzymology, v. 136, p. 432-454, 1987.

CHEETHAM, P. S. J.; GARRETT, C.; CLARK, J. Isomaltulose production using immobilized cells. Biotechnology \& Bioengineering, v. 27, p. 471-481, 1985.

CHEETHAM, P. S. J.; IMBER, C. E.; ISHERWOOD, J. The formation of isomaltulose by immobilized Erwinia rhapontici. Nature, v. 299, p. 628-631, 1982.

HÄBERER, D. et al. Beneficial effects on glucose metabolism of chronic feeding of isomaltulose versus sucrose in rats. Annals of Nutrition and Metabolism, v. 54, p. 75-82, 2009.

HASHIMOTO, H.; YAMADA, K.; YOSHIMURA, J. Glucosylation of methyl $\beta$-D-arabinofuranoside with 6'-chloro-6'-deoxysucrose and immobilized Protaminobacter rubrum. Biotechnology Letters, v. 9, n. 12, p. 849-854, 1987.

HUANG, J. H.; HSU, L. H.; SU, Y. C. Conversion of sucrose to isomaltulose by Klebsiella planticola CCRC 19112. The Journal of Industrial Microbiology and Biotechnology, v. 21, p. 22-27, 1998.

HULST, A. C.; TRAMPER, J. Immobilized plant cells: a literature survey. Enzyme and Microbial Technology, v. 11, p. 546-558, 1989.

KAWAGUTI, H. Y.; MANRICH, E.; SATO, H. H. Production of isomaltulose using Erwinia sp. D12 cells: culture medium optimization and cell immobilization in alginate. Biochemical Engineering Journal, v. 29, p. 270-277, 2006.

KASHIMURA, J.; KIMURA, M.; ITOKAWA, Y. The effects of isomaltulose-based oligomers feeding and calcium deficiency on mineral retention in rats. Journal of Nutritional Science and Vitaminology, v .42, p. 69-76, 1996.

KASHIMURA, J.; NAGAI, Y.; GODA, T. Inhibitory action of palatinose and its hydrogenated derivatives on the hydrolysis of a-glucosylsaccharides in the small intestine. Journal of Agricultural and Food Chemistry, v. 56, p. 5892-5895, 2008.

KRASTANOV, A. et al. Conversion of sucrose into palatinose in a batch and continuous processes by immobilized Serratia plymuthica cells. Enzyme and Microbial Technology, v. 39, p. 1306-1312, 2006.

KRASTANOV, A.; BLAZHEVA, D.; STANCHE, V. Sucrose conversion into palatinose with immobilized Serratia plymuthica cells in a hollow-fibre bioreactor. Applied Biochemistry and Biotechnology, v. 162, p. 89-102, 2007.

KRASTANOV, A.; YOSHIDA, A. Production of palatinose using Serratia plymuthica cells immobilized in chitosan. Journal of Industrial Microbiology and Biotechnology, v. 30, p. 593-598, 2003. 
LICHTENTHALER, F. W.; PETERS, S. Carbohydrates as green raw materials for the chemical industry. Comptes Rendus Chimie, v. 7, p. 65-90, 2004.

MORAES, A. L. L. et al. Produção de isomaltulose a partir da transformação enzimática da sacarose, utilizando-se Erwinia sp D12 imobilizada com alginato de cálcio. Ciência e Tecnologia de Alimentos, v. 25, n. 1, p. 95-102, 2005.

MUNDRA, P., DESAI, K., LELE, S. S. Aplication of response surface methodology to cell immobilization for the production of isomaltulose. Bioresource Technology, v. 98, p. 2892-2896, 2007.

SHIMIZU, J.; SUZUKI, K.; NAKAJIMA, Y. Method of producing an immobilized alpha-glucosyltransferase useful in the production of palatinose from sucrose. GB Patent 2.082.591, 1982.
TAKAZOE, I. Palatinose- An Isomeric Alternative to Sucrose. In: ELSEVIER APPLIED SCIENCE (Ed). Progress in Sweeteners. London, England: Elsevier, 1989. p. 143-167

TSUYUKI, K. et al. Isolation and characterization of trealuloseproducing bacteria from Thailand soil. Journal General Applied Microbiology, v. 38, p. 483-490, 1992.

VORLOP, K. D.; KLEIN, J. Formation of biocatalysts by ionotropic gelation. In: LAFFERTY, R. M. (Ed) New developments in the field of cell immobilization. Enzyme Technology, Springer, 1983. p. 219-235.

WU, L.; BIRCH, R. G. Characterization of the highly efficiente sucrose isomerase from Pantoea dispersa UQ68J and cloning of the sucrose isomerase gene. Applied and Environmental Microbiology, v. 71, p. 1581-1590, 2005. 